\title{
Political Economy of Public Broadcasting in Nigeria: A Review on Influence of Deregulation and Commercialisation in Public Access and Participation
}

\author{
Adamkolo Mohammed Ibrahim* \\ Department of Mass Communication, University of Maiduguri, PMB 1069 Maiduguri, Borno State, Nigeria; \\ Department of Mass Communication, Bayero University Kano, PMB 3011 Kano, Kano State, Nigeria \\ Suleiman Mainasara Yar'Adua \\ Department of Mass Communication, Bayero University Kano, PMB 3011 Kano, Kano State, Nigeria \\ Balarabe Maikaba \\ Department of Mass Communication, Bayero University Kano, PMB 3011 Kano, Kano State, Nigeria
}

\begin{abstract}
In Nigeria, the public broadcast media system was originally designed to be in the forefront of promoting human development, democracy, peaceful coexistence, transparency, rule of law and serving as mediators of the public sphere. However, the public broadcast media in the country have not been successful in playing these roles fully when compared to the print media, for example. Apart from being in predominantly urban areas, public broadcast media in Nigeria are largely elitist and heavily commercialised in their programming and content. Hence, factors such as deregulation, liberalisation and commercialisation of the broadcast media industry have impacted negatively on how public broadcast media are perceived by the audience and other players in the industry. This paper seeks to analyse the effect of deregulation and commercialisation of the broadcast media in Nigeria since 1992 on public broadcast media's accessibility and public participation for a broad range of segments in society, the rich, the poor, marginalised groups and women. Using critical discourse analysis approach, extant literature was critically reviewed, and a theoretical framework was conceptualised for adoption in future research. Recommendation for future research is given at the end of the paper.
\end{abstract}

Keywords: Commercialisation, Deregulation, Nigerian broadcast media, Political economy of communication, Political economy of public broadcasting

DOI: $10.7176 / \mathrm{NMMC} / 84-01$

Publication date:October $31^{\text {st }} 2019$

\section{Introduction}

As the title reflects, this paper analyses issues surrounding the political economy of public broadcasting in Nigeria. However, given that the duo of the key concepts of this paper, 'political economy' and 'public broadcasting' have vastly wide scopes and, could, certainly be beyond the limitations of this paper (which include timeframe, none-thesis paper), for convenience, therefore, the authors chose to focus on deregulation and commercialisation components of political economy.

Deregulation, liberalisation and commercialisation of the broadcast media have had unintended negative effect on how public broadcast media are perceived by the audience and other players in the media industry. As [1] noted, liberalisation has "widened the avenue for cultural imperialism", minimizing veritable platform for national cultural expression. According to him: "during the era of government monopolisation of the broadcast industry, profit motive was not a major factor in programming. But in this era of liberalisation, the case is reversed. Thus, powered by the profit motive, private broadcast stations invest more in programmes that people "want rather then what they need" (p.8). Another question is the role of deregulation and commercialisation in shaping access to and participation of the public in broadcast media programmes. This paper attempts to respond to these issues. This is because public broadcast media outlets that are participatory and dialogic, for example, radio, provide the highest possible ingredient for national cohesion and peaceful coexistence. This paper seeks to analyse the effect of deregulation and commercialisation of the broadcast media in Nigeria since 1992.

Specifically, this paper focuses on radio and television stations, the nature of their programming decisions and what informs them. It studies the effect of deregulation on access and participation for the masses. In what ways have access and participation been constricted or improved for these groups as a result of deregulation and commercialisation of radio and television? The deregulation and commercialisation of the broadcast media were the demand of international political economy through the Structural Adjustment Programme (SAP) and other economic revival programmes of the Bretton Wood institutions, the World Bank and the International Monetary Fund (IMF). They were framed as market-driven policies that would, purportedly, reduce state-funded wastages and lead to economic prosperity, diversity and the ascendancy of market-driven democracy of choice [4, 42]. 
The proposed conceptual framework and model that guide this analysis of deregulation and commercialisation of broadcasting are key ideas on the literature of the political economy of communication. The analysis is on the ways in which political and economic structures and processes, in this case, the public policy of deregulation and commercialisation of broadcasting impinge upon the production, dissemination and appropriation of communication by economic forces seeking profit. The critical political economy of communication sets out to show how different methods of financing and organising our communicative needs, including ownership have consequences for the range of discourses and representations within the public domain and for audiences' access to them [2].

\section{Background}

Prior to the ascension of General Ibrahim Babangida as the Military President of Nigeria in August 1985, two previous regimes had attempted to grapple with Nigeria's economic crisis. Both regimes of General Obasanjo and Alhaji Shehu Shagari had put in place austerity measures to reverse the precipitous decline in oil revenues in 1977 and an Economic Stabilisation Act in 1982 called austerity measures respectively. The regime of General Ibrahim Babangida surrendered to the pressures of the International Monetary Fund's packaged Structural Adjustment Programme (SAP) [3]. After capitulation to the IMF's demand to adopt a structural adjustment programme, Nigeria implemented components of the programme [4].

This paper is specifically concerned with the commercialisation and deregulation components of the IMF, particularly Decree No. 25 of 1988 listed a total of 35 enterprises for commercialisation, 24 were for partial commercialisation while 11 were for full commercialisation. That decree 25 provided the legal framework for the Government's programme of commercialisation as an important component of the restructuring of the Nigerian economy. Under that decree, commercialisation was defined as the reorganisation of enterprises wholly or partly owned by the Federal Government in which such commercialised enterprises shall operate as profitmaking commercial ventures and without subvention from the Federal Government $[5,6]$.

Although there was a widely held notion that commercialisation and deregulation of the broadcast media will democratise communication and increase access and participation for a broad range of citizens, the problems of access, as well as participation for ordinary people remains unsolved. Media have, therefore become increasingly competitive and hence, access and participation are out of the reach of the poor, making them more marginalised and excluded [7, 8]. Deregulation of broadcasting thus became a new site for capital accumulation for the rich, particularly advertisers and media owners. Deregulation constricts the space for public service broadcasting, limiting educational, informational, developmental and peacebuilding content in radio in Nigeria [9]. This paper assesses how deregulation and commercialisation of radio and television stations shape programming decisions, access and audience participation in in Nigeria.

\subsection{Statement of Problem}

Despite the arguments on the importance of the market as the fulcrum of policies leading to deregulation, liberalisation and commercialisation, there are pitfalls in the implementation of policies emanating from the West, which, while suited for their levels of development, might be detrimental to a developing economy such as Nigeria $[10,11,12]$. This is important because public radio and television stations, which are required to play a significant role in national development might be hampered by deregulation with reference to the commercialisation of news, content and programming.

The logic of deregulation informs the logic of the commercial system as Williams (1968) cited in [13] posits "anything can be said, provided that you can afford to say it and that you can say it profitably" (p.119). This implies that a large chunk of citizens who cannot afford to finance and operate media are marginalised, contents and messages that are necessary for human development would be excluded. Similarly, the profit orientation of the commercial media significantly reduces the range of content being communicated $[14,15]$. This paper therefore assesses how deregulation and commercialisation have affected the programming and content of public radio and television in Nigeria, focusing on access and participation.

\subsection{Aims and Objectives}

The purpose of this study is to examine how deregulation and commercialisation of the broadcast industry have shaped the operations of public radio and television stations in the country. Public broadcasting, in this case, provides an important platform for public awareness and information sharing, education, political participation and development according to Asemah (2011), McQuail (2005) and Salter (2011) cited in [16]. The radio and television communication technologies have the greatest potential to support development, peace building and deradicalisation through their content $[17,18,19]$. However, in a fully deregulated and commercialised environment, this great potential could be diminished due to an increased focus on private commercial interest (profit making) by public broadcast stations. It is, therefore, important to study deregulation and commercialisation of public broadcasting and to understand what new forms of economic, social or political 
consequences they engender. Considering the above, this paper aims to determine how deregulation and commercialisation have shaped programming content, e.g., in peacebuilding, development, political mobilisation and education.

\section{Literature Review \\ 3.1 Overview}

In this section the paper looks at the British and United States' (US) models of broadcasting to identify how both models shaped what is currently known as the Nigerian model of broadcasting. Included in this section is the concept of deregulation and commercialisation and their implementation, particularly in Nigerian public broadcast industry. Finally, the last section of this chapter provides an overview of the proposed theoretical/conceptual frameworks designed based on political economy of communication and the democratic participant theory of communication.

\subsection{The Presence of Commercialisation in Public Broadcasting}

\subsubsection{The United State Commercial Broadcast Media Model}

Commercial broadcasting first started as a phenomenon in the US. Regarded as the 'fourth dimension' of the advertising quadrangle after billboards, magazines and newspapers, commercial advertising on broadcast media, particularly radio, completed the appeal to all the senses [20]. The American way of life, their orientation to business and a nation whose independence was founded on the demand for freedom of trade, free and private enterprise and a rational competitive spirit made it a fertile ground for the first use of radio for commercial advertising [21]. The commercialisation of radio did not come at once. It was tentative and slow especially given opposition to the whole idea of filling the airwaves and the still exotic medium with 'advertising chatter.' The first radio station, known as the KDKA went on air in 1920 in Pittsburgh, USA. Nobody knew how to make money from broadcasting. The broadcasting, especially radio was new and took everybody by surprise. Some people thought that broadcast services could be paid for through metres like electricity while others thought that manufacturers of receiving sets (Radio and television) would support radio and television stations and provide programming to boost the sales of receiving sets $[22,4]$.

However, within a few years, broadcasters sold radio airtime to sponsors and advertising became the financial basis of broadcasting. This support for broadcasting by advertising affected both the structure of the industry and the form of broadcast programming. By the mid-1930s, a fully commercialised radio broadcasting was in place in the US and was carried over into television in the late 1940s. This phenomenon was preceded by attempts in the American system to avoid the commercialisation of the electronic media. Initially, manufacturers of radio receiving devices supported the first transmitting stations. Privately owned radio stations also asked listeners for contributions during the late 1920s. The Radio Music Fund Committee sought gifts to engage the best musical talents, artists to perform over WEAF in New York [20,4]. The development of a commercialised radio is intricately tied to the American free enterprise spirit.

\subsubsection{Resistance to Commercial Presence in Public Broadcasting}

Despite the strong belief in the spirit of free enterprise and invisible hand of market forces, there was strong opposition in the early attempts of broadcasting to unbridled commercialism. Early attempts by the US Congress to reform or regulate broadcast industry paid scant attention to the issue of commercialism. Attempts were focused mostly on licensing and frequency allocation. The 1927 Radio Act created the Federal Radio Commission (FRC), which was empowered to issue licenses. In 1932, following charges of bias against noncommercial radio, a congressional directive led to a survey of commercial presence in the US Radio system. The report was overwhelmingly supportive of commercialism in broadcasting. The Federal Radio Commission explained that at least, one-third of radio broadcasts were commercial while the rest of the airtime was filled with non-commercial programmes. The FRC reasoned that this policy was a way through which stations helped to serve the public interest as mandated by the 1927 Radio Act, and enlarged and held an audience, thereby increasing the value of time available for commercial programmes [20,4].

Observers of early radio and television broadcast had worried about the potential influence of commercialism on broadcast media. Opposed to the idea of commercialisation were a small but vocal group of educators and reformers who feared a national broadcasting system controlled by powerful commercial interests and advertisers. They worked hard to prevent such a system. Some suggested that specific wavelengths be set aside exclusively for the dissemination of educational materials, this band could be used by universities and colleges and the widening of broadcasts to include isolated communities, people in the farms to gain access to the media for information and education [4, 42].

Although congress voted for the ascendancy of commercialism in broadcasting, continued pressure from reformers, educators and grassroots organisations led to the US system giving concession to public broadcasting in 1967. In the 1950s, the Ford Foundation put in money into the efforts of the educational broadcasters' lobby with a view to energising it for greater success. By this time, television has joined radio as the second broadcast 
medium of mass communication and this gave an added impetus to the lobby. The Public Broadcasting Act of 1967 established a Corporation for public broadcasting to help develop public television and radio stations, and programming of "high quality, diversity, creativity, excellence and innovation." However, the 1996 Telecommunication Act which completely deregulated the media made no requirements of public interest on operators of the new media $[23,4]$.

In recent times, America's policy instruments in entrenching the hyper commercialisation of radio and television is through budget cuts or stagnation of levels of funds already appropriated. In his 2017 budget, President Trump maintained levels of funding to the Corporation of Public Broadcasting, the country's noncommercial broadcaster [4], while revenue from public commercial broadcasting soared to over 19 billion Dollars [24]. Although within the period, the Federal Communication Commission opened a tiny funding reprieve by allowing the noncommercial broadcast station to embark on third party fundraising, this relaxation allows noncommercial broadcast stations to raise money for well-meaning and public interest causes, "such as disaster relief and assistance for the poor, while educating their audiences about important issues. Stations that engage in this type of fundraising can only be reimbursed by the third party for their expenses directly related to the fundraiser" [25].

However, in 2018, the financial lifeblood of noncommercial broadcasting was reduced when President Trump's budget cut funding to the Corporation of Public Broadcasting and the National Public Radio by 30 million Dollars [27]. Reference [28], who served as the Chairman of the Federal Communications Commission from 2013-2017 recently noted that through revocations of regulations meant to protect local broadcasting against the effects of unbridled commercialisation, the US' broadcast policy is killing local programmes and productions in the broadcast media [4].

\subsubsection{Public Interest in Broadcasting}

In tracing the history of commercialisation, the opposition to it, in the two different broadcasting models, two recurring expressions are found: the free market and the public interest/public service. The concept of the free market, its origins and essential features has been discussed in the previous section. In this section, the concept of public interest and the public sphere in broadcasting is discussed.

The concept of public interest has engaged political scientists for years. They have grappled with a shifting conceptual framework in the definition of what is public interest. From the crass vulgarity of the former chairman of the US Federal Communications Commission's [26] Mark Fowlers' definition of public interest, "Public interest is whatever the public is interested in", to Frank Stanton, former CBS chairman's definition of public interest as "A programme in which a large part of the audience is interested in, is by that very fact... in the public interest"; and David Sarnoff's (former NBC Chairman) definition, "public interest is whatever the public chooses to watch and listen to" [29], public interest remains a thorny and controversial issue. Despite all these uncertainties and controversies about the significance of the concept of 'public interest', this concept has been deeply integrated into the development of broadcasting [4].

Ever since the initial launching of broadcasting in the US, the approach to broadcasting has created a constant tension among the several objectives that the broadcasters must serve concurrently - operating as business and following the US congressional mandates and their Federal Communications Commission (FCC) and the public interest [30]. Both the Radio Act of 1927 and the FCC Act of 1934 required the licensed stations to operate in the "public interest, convenience or necessity" [4].

The provisions of National Broadcasting Commission (NBC) to Nigerian license holders require them to foster national growth and development through presenting all issues of public interest fairly to the Nigerian people, recognising that they (the licensed broadcasters) hold the licenses in trust for the people. The US Radio Act of 1927 upheld some important items that have been regarded as significant for the future development of non-commercial broadcasting system. It stated that the spectrum is a natural resource belonging to the people and therefore, a private person cannot own a channel but can use one for private purposes only if such also serves the public interest. This act also granted the government discretionary powers to regulate radio and television communications limited by the "public interest, convenience or necessity" [31, 4].

\subsection{The Presence of Public Interest in Broadcasting}

\subsubsection{The British Model}

While the US voted for a free market model, most of Europe and Asia and Japan, for example, favoured the public service/public interest model. The nature of European socio-economic configuration and the ascendancy of aristocracy were important influences that shaped the choice of public service model of broadcasting [21, 4]. In Europe, the British model of public service broadcasting (PSB) is the best example of the public interest approach. The British experiment with PSB was to avoid the chaos and "air war" taking place in the broadcasting landscape in America in the early days of radio. In 1929, the Postmaster-General, the officer in charge of wavelengths and frequencies in Britain told the House of Commons that in contrast to the American situation "what we are now doing at the beginning is to lay down very drastic regulations indeed for the control 
of wireless broadcasting" [32,4]. The British post office had the task and was concerned about how to allocate wavelengths to all who had applied for it, the armed forces, maritime commercial shipping, wireless telegraph companies, etc. The frequency spectrum was not limitless, hence, the need to ration it [42].

The establishment of the BBC was a farsighted action to avoid control of broadcasting in the United Kingdom (UK) by several competing companies like the Marconi Company and several companies manufacturing radio and television receiving sets. Monopoly of broadcasting by the BBC was a compromise to avoid the monopoly of another kind; the commercial monopoly of broadcasting by a group of manufacturing companies and the Marconi Company, which had happened in the US. It was therefore agreed that the commercial companies should be replaced by a public corporation, licensed for ten years and "acting as a trustee for the national interest in broadcasting" [32]. The Crawford Committee, which considered how broadcasting should be in the UK recommended that a board of governors should be appointed by the government to serve for five years. The British Parliament was asked to grant maximum freedom to the corporation and it (the corporation) must be allowed to broadcast any issue no matter how controversial [4].

\subsubsection{Financing Public Radio Broadcasting}

Public service broadcasting especially its funding by the state has been under attack for a long time [33, 34, 35]. The ascendancy of free market orthodoxy, which questions the role of the state and state-owned enterprises eroded the argument of spectrum scarcity, which was the pillar of arguments for PSB funding. Despite the arguments, according to a report by [36], funding for public service has not declined over time. There has been shifts in funding mechanisms and models but not decrease in funding in Europe, US and Canada until recently. "Regardless of the model on intervention, funding for PSB remains strong. Growth as a percentage of current funding levels was particularly strong in countries with lower levels of PSB funding" [36, 4]. The Reference [37's] study on public and private broadcasters across the world in 2013 validates this position.

There were several ways of funding PSB in the past. These remain but new funding mechanisms and models have emerged, but four main methods remain the most used: (1) direct state grant: this is another method of funding PSBs. In some cases, this follows a decline in the license fee often inflation and the state have eroded the value lacks the political will to increase the fees. Direct grants were favoured by the government of Nigeria before deregulation and continues in some forms today. This funding method exposes the PSB to undue interference and political pressure from the state; (2) hypothecated taxes: these are levied on businesses or consumers and represents a new and stable method of funding PSBs. There are two types of hypothecated taxes, namely those levied on individuals and those levied on companies. For example, in Italy, Greece and Portugal, a certain percentage of consumers' electricity bills is reserved for PSBs [14]. There are also the hypothecated taxes reserved solely for companies like in Spain and France where telecommunication companies pay a certain amount for PSBs; (3) public grant: this is yet another form of funding methodology used a lot by countries. Public grants can be a one-off grant for special projects like digitisation or any special projects. An example is the BBC World Service, which was funded by the Foreign and Commonwealth grants for so many years. Some countries like Canada, Spain, Portugal and Australia use public grants as the main source of funding for their public service broadcasters. Commercial revenue from advertising or sale of programmes is part of the funding mix but hardly provides enough funding for PSBs. A report by [37, 36] notes that license fees generate only $23 \%$ of revenues for its operations while in France more than $70 \%$ of its operations are financed through license fees. In the US, the Corporation for Public Broadcasting, a tax-funded non-profit provides about $20 \%$ of all funding for non-profit broadcasting [38]. This disparate funding mechanisms have led to calls for a mix of funding methods, waivers, tax havens, foundations, in addition to the foregoing [39]; and (4) license fees: this remains the most popular way of funding PSBs. License fees are charged to devices capable of receiving specified broadcasts. Governments decide on what devices should be charged and who collects the fees, either itself or the broadcaster. License fee funding provides a stable long year of funding. It reduces the dependence on revenue from advertising and direct funding from the state [4].

\subsection{The Nigerian Public Broadcasting Model}

\subsubsection{A Hybrid Approach}

The Nigerian model is a hybrid of both the British and American broadcasting models, suing both economics and geopolitical imperatives, combined government media, ownership with commercial broadcasting - a nuance departure from the tax supported BBC model. The hybrid model is a mix of commercialisation and public interest. For public interest, the model takes a progressive approach to the application of public radio and television for service for the "public good, market-determined and not what government prescribed as being desirable." Further, using the commercialisation approach, the Nigerian model uses the US competitive market approach, which focusses on free enterprise [38, 4].

Being a colonial entity in 1951, the Nigerian broadcasting system would not be different from the British system. Reference [26] tends to believe that the introduction of broadcasting first with the Radio Distribution Service (RDS) before mainstream broadcasting proper was responsible for the public service model of Nigerian 
broadcasting. Governor-General MacPherson insisted from the beginning that the Nigerian Broadcasting Service (NBS) be non-commercial but permitted the development and expansion of new RDS operations. Commercially operated and privately owned, most of such operations were run by British Companies. Hence, while the RDS systems ran advertising particularly on the local level, the newly born NBS was not permitted by the British colonial government to advertise and had to rely on annual license fees for its revenues $[25,4]$.

In the US, both the Radio Act of 1927 and the FCC Act of 1934 required the licensed Stations to operate in the "public interest, convenience or necessity." The Radio Act of 1927 upheld some important items that have been regarded as significant for the future development of non-commercial broadcasting system. It stated that the spectrum is a natural resource belonging to the people and therefore a private person cannot own a channel but can use one for private purposes only if such also serves the public interest. This act also granted the government discretionary powers to regulate radio communications limited by the "public interest, convenience or necessity" [31].

The UK bequeathed the public interest model to its former colony. The Governor-General and his staff left behind a broadcasting culture "patterned on the tradition of the BBC." The first corps of staff of the Nigerian Broadcasting Service was seconded from the BBC and the BBC trained the corps of Nigerian Staff. According to the 1956 Ordinance, the Nigerian Broadcasting Corporation (NBC) was to run as a public service without selling airtime but supported by license fees just like the BBC. However, this contradiction of running two different broadcasting models was met with stiff opposition by the elite of the day, especially within the Lagos and Ibadan axis. They felt that it was exploitative and discriminatory against Nigerian broadcasting and the Nigerian people $[14,4]$.

When the regional broadcasting services took off on the strength of the 1954 constitutional provision, they began immediately running commercial services, accepting personal paid announcements and sponsored adverts. Thus, for so many years until 1988, Nigeria had a non-commercial public service national broadcasting system and a regional/states commercial broadcasting system. A mixture of the British and American models, the only difference being that both of Nigeria's systems were government-controlled unlike the privately driven American system. The provisions of National Broadcasting Commission (NBC) to Nigerian license holders require them to foster national growth and development through presenting all issues of public interest fairly to the Nigerian people recognising that they hold the licenses in trust for the people [31, 14, 4].

3.4.2 Financing the Nigerian Public Broadcast Model

The Broadcasting Act provides that the NBC relies on license fees for its operation. However, with the estimated 143,000 broadcast receiving sets present in Nigerian homes in 1960 and an annual license fee of 10 shillings charged by the NBC, it was not difficult to foresee trouble. The problem was that most radio sets owners in Nigeria then earned an annual salary of 30 Pounds and the license fee of 10 shillings represented $3.3 \%$ of their annual income. The implication is that most radio set owners could not pay [39, 40]. The then colonial government resolved that the license fee revenue be used for the development of NBC programming and facilities while the government subsidised the NBC capital budget. The regional stations apparently were better off financially than the NBC because they derived revenues from three sources. Their various governments subvented them, they ran commercial advertising and charged a regional license fee like that charged by the NBC $[38,4]$.

From its origin, the Nigerian broadcasting was national and non-commercial like the British system. The British used the BBC, its own national broadcaster as a model for the Nigerian system. When regional stations took off, they copied the commercial re-diffusion system, which existed before the NBC and ran advertising from the beginning. The license fee system was not funding broadcasting adequately. Hence, the Federal Government had to give subvention for capital and recurrent expenditures to the NBC. The regional stations even though they ran advertising and collected license fees, still had to rely on their governments to fund capital projects. Reference [41] notes that media and communication policy vacillate between the market, underpinned by deregulation and commercialisation and the public interest. The American model is anchored on the market model of private ownership to engender the "marketisation of ideas" while the UK model, as most Europe, placed more importance on public service broadcasting, which emphasises a strong relationship with the public.

As a former British colony, Nigeria at independence adopted the British public service model. However, the American model of market-oriented broadcasting policy became flown blown in Nigeria as part of the package of the International Monetary Fund and World Bank-supervised economic recovery tools like SAP [43, 5]. The policy of deregulation and commercialisation are outcomes of the globalised economy spearheaded by the neoclassical orthodoxy of the US, hence the upsurge of marketisation of broadcasting in Nigeria. The neoclassical attacks on state institutions and state financing as inefficient ushered in the marketisation of emerging economies like Nigeria. These neoliberal tendencies promoted by international actors like the World Bank and the IMF promote the interest of the global capitalist elites like the US [43]. Some of the outcomes of this as noted by [44] are forms of cultural imperialism in content and policy.

In 1988, at the height of the Structural Adjustment Programme, through the Federal Radio Corporation of 
Nigeria (FRCN) Amendment Decree 1988, FRCN became a partially commercialised organisation. With this ended, the era of the FRCN being solely involved in public broadcasting with government subvention as the sole source of its revenue. The corporation had to from then on hustle with the states' stations in the marketplace for financial survival. The situation was further compounded and made more precarious for the financial survival of the corporation with deregulation of the broadcasting industry in 1992 [36, 4].

This meant that for first time government was no longer the sole sponsor and provider of broadcasting in Nigeria, individual and the private sector moved in 1992. The decree meant that government funding of the system was divested to allow for a certain degree of commercialisation as an independent source of revenue. It was also decreed that the FRCN would continue to provide social services as a model for PSB in Nigeria despite its partial commercialisation. The incompatibility of rational market forces and public service was glossed over in the decree. In the Nigerian system, commercialisation of the public broadcasting media represented by the FRCN and the Nigerian Television Authority (NTA), took place within a military dictatorship. This may have contributed to the lack of opposition to it or perhaps people lacked adequate knowledge of what the impact would be $[41,44,4]$.

However, this cannot be said of the academia, the educationists who had in 1974, moved for the use of radio for adult and non-formal education and as well as the vigorous pursuit of a Schools broadcasting system. There was some opposition to the commercialisation project by a few like Dr. Christopher Kolade, who was the Director-General of the FRCN and expectedly from the states stations who feared that the network reach of the FRCN and the NTA would deprive them patronage from advertiser [28]. Reference [4] noted that there was strong agitation for the deregulation aspect of the medium by the private sector that wanted to participate in what was thought to be the lucrative business of broadcasting.

\subsubsection{The Fall of the Public Interest Model}

The section above describes how broadcasting in its very beginning incorporated the concept of the public interest. The American model though private sector led was regulated to ensure that it operated in the public interest. The US Federal Communication Commission (FCC) in 1946 set the standards of what should be considered in the public interest in its memorandum; "The public service responsibility of Broadcasting Licensees." According to the 'Blue Book', as it came to be known, broadcasting stations were expected to balance their programming by including in their weekly schedules reasonable numbers of programmes on education, news, agricultural information and issues of public importance as well as programmes serving the interests of local non-profit civic and religious groups and labour organisation and progammes intended to appeal to minority interests and tasks such as classical music. In addition, the number of commercial sponsored programmes and the number of advertisements included in the station's weekly schedules were to be limited [44].

It was a public policy in the UK right from the start to broadcast in the public interest using John Reith's ethos of PSB as guardian of the national culture, to focus in bringing education, information and entertainment to the whole country. This has been of profound social and cultural benefits to the British society. It is still operated to reinforce the democratic open nature of the society. The Nigerian broadcasting system had also in its mandate to broadcast in the public interest to enlighten the citizenry, mobilise and bring government closer to the people. It was to be a forum for education, information and entertainment. It was mandated to uplift the culture of the people and unite them. But the 1980s saw a gradual decline in concerns for the public interest and its protection by the state. In 1984, the US FCC deregulated some aspects of both radio and television broadcasting by removing the requirements for public interest programming and allowing increased airtime for commercial messages $[44,4]$.

Finally, in 1996, the Federal Communication Act removed whatever was left of requirements for public interest in American programming with a full deregulation of the sector. Given its public service tradition, the $\mathrm{BBC}$ has been more resilient in fighting the onslaught of commercialism since 1954 with the establishment of the Independent Broadcasting Association that broke its monopoly on broadcasting. A committee was set up to consider the issue of alternative funding for the BBC. The Pilkington Committee's Report as published in 1962 was a huge vindication of broadcasting as seen by the $\mathrm{BBC}$, public service values were praised, commercial values seriously questioned. BBC gained everything it wanted, new Channel, colour, a switch to 625-line, maintenance of license fees as the source of revenue [45, 46].

References [47, 48] believe that the notion of a public interest cannot be completely removed from the fabric of societies to which they are applied and that in the last 20 years, most modern societies have changed in ways that make the public interest in communication more difficult to define and to implement. They identified six processes of transformation of these societies that impinge on the public interest. They are: (1) consumerism: the increased channeling of personal goals toward the consumer role, and the pervasive encouragement of commercialisation that results; (2) privatisation: more preoccupation with personal domestic pursuits and reduced involvement in public commercial ones, a diminishing "social capital" [48]; (3) individualisation: this means the elevation of personal aspiration, fragmentation of communal experience, reduced conformity to the tradition and demands of established institution; (4) specialisation and social complexity: an increased 
differentiation of functions performed by societies subsystems and the emergence of more subgroups with their own formed, identities, goals and political strategies; (5) globalisation: increased awareness of and engagement with events, personalities, ways of living and cultures beyond one's national borders [47]; and (6) Antiauthoritarianism: increased skepticism about the credentials, claims, performance and credibility of authority holders in all walks of life.

These trends are inimical to the concept of public interest. They reduce public life, institutions, authority, and diminish the realisation of the public interest in the media arena. They regard previous attempts at public interest as old fashioned and belonging to needs and societal conditions that no longer exists and values that no longer apply. The strongest impetus against the decline of public interest and use of commercialism, can be found in the economic sectors. This position by Professor Friedman for maximum profit making against social responsibility is based on the dialectics of 'what is in the public interest?' and 'What is social responsibility?' [4].

Reference $[49,50]$ believe that determining social responsibility or public interest is so subjective that it is useless for anyone to decide what constitutes a socially responsible public interest corporate act. For instance, in the UK there was the establishment of the Independent Television Network to further break down the monopoly of the BBC while in the US congress enacted a public broadcasting Act in 1967 in response to the public interest lobbyists. In the 1980s came deregulation. Reference $[51,50]$ believe that in the US deregulation was a response to a situation in which "non-dominant groups were beginning to achieve success in applying pressure on the regulatory apparatus to implement public interest values more frequently [...] deregulation is one way the state reforms itself to eliminate the arena of potential class conflict".

This view was supported by [51] who argued that that the relentless aggressive onslaught of the free market economy with its emphasis on commercialisation and deregulation is predicated on the fall of the Soviet Union and the present unipolar global structure. Reference [51] notes here that the ideological buffer and alternative modes of production provided by the former Soviet Union having been removed with the collapse of communism, gave an unfettered reign to the onslaught of the marketisation of the global economy. Keynesian economics and the era of state-supported social policies and programmes were over. Broadcasting, considered for decades as a social good for the public would now have to contend for relevance in the market place and the 'invisible hand' would now determine if it can still play a role, like other media forms, in national development. 3.4.4 The Third World Political Economy of Communication

For Nigeria, like other third world countries, the political economy of communication and information as distinct from other variants has noted the centrality of the broadcast media as a vehicle for national development, integration, social mobilisation and education. Even before the political economy of communication gained currency as an analytical tool, Western modernisation theorists that sought to incorporate the African continent into the Western capitalist mode of thinking and production and a buffer to the post-Second World War ravages of soviet communism had positioned the media as a tool for modernisation, for breaking down traditionalism and creating the liberating environment for economic development and the disintegration of 'backward' values [4].

From the economic plank, people like WW Rostow had hypothesised the basis and stages of economic growth for the Third World, which precluded a communist manifesto. Public broadcast media's potential and efficiency have been measured largely because of their ability to reach unlimited numbers of people in a continent devoid of basic infrastructures like electricity. Hence as an instrument, the information technologies of radio and television have been used for public enlightenment messages, in health, education, agriculture and other non-formal educational types of programmes that had attempted to replicate formal education [52, 53, 54]. Equally, governments have used radio and television for social and national integration and mass mobilisation for efforts like the civil war in Nigeria, Environmental education, infant immunisation, political and democratic participation. Commercialisation and deregulation take place when the State withdraws regulation based on public interest, public service with forms of regulation by markets. Practically this means that a lot more emphasis is placed on the market as the regulator through profit motive, the audience size and revenue from advertising. Opponents of this model maintain that commercial based decision making inevitably means one class of users' benefits over others $[55,56]$.

Two models opposed to each other are the central issues in the debate of public broadcast media deregulation and commercialisation. The struggle between the two models are about citizenship, enlightenment, democratic rights and freedoms in the realms of cultural productions and what economics and market forces will deliver to the people. One model maintains that the sustenance and the general well-being of society and its culture is dependent on the political subsystem to make strategic decisions and intervene through state agencies for the 'public good' $[57,11]$. On the other spectrum of the argument are antagonists of any form of regulation or intervention by the political subsystem through public policy. They argue that in a democratic society the state should be minimalist and not interfere in choices people make on matters of audio-visuals, on what to listen to or watch. Reference [45] argues:

Here then are two models between which the audience-as-citizen is being asked to choose: policy guided by the hand of 'public' regulation employing 'public'values, serving the 
'public' interest; and policy as the ad hoc result of a myriad individual choice with the collective good and interest in effect being what the public, using economic judgment, say they are. In country after country one can see a collision between a cultural civic model for development of broadcasting and the 'economic' or circus model for the larger construction of a culture of communication of which television and radio are part. (p.12)

Nevertheless, the public service model of broadcasting given experiences from the Third World has not been all roses and no thorns because of its hegemonic tendencies of reflecting the ideas and ideologies of power and social relations. Yet, it may have nurtured Nigeria and supported it through its most difficult periods in history, mobilising, educating and entertaining by excellent programmes, high standards of creativity and patriotism, shaping the future of society and its culture. The European model of public broadcasting which Nigeria copied in its early history, is a model that factors in this mediating role of the media for democratic health, "the tradition of western European democratic theory and practice situates modes of public communication at the heart of the democratic process within the very core of the notion of civil society" [45]. While those who favour a complete deregulated and commercialised media environment would counter that in a multi-channel environment, the public sphere is enriched rather than constricted, they point to the multiplicity of the media landscape of the US as the triumph of peoples' power, the freedom to choose from a market determined staple [58].

A social policy for communication should be based on the people's real communication and information needs rather than on what the market supply makes available [59]. The rhetoric of deregulation and commercialisation that swept the globe in the 1980s was therefore a response to the gradual emergence of an international public sphere in which economic activities have become transnationalised. This process of globalisation has been boosted over the last 35 years by a shift in favour of market forces as well as in the widespread adoption of policies of deregulation and economic liberalisation on a global scale [61, 60]. For Nigeria, it was the need for an economic recovery that thrust the policy on it, and this affected the broadcast media [4].

\subsection{Hypotheses}

The following hypotheses were formulated based on the literature review.

H1: There is a significant relationship between deregulation and access and participation.

$\mathrm{H} 2$ : There is a significant relationship between commercialisation and access and participation.

H3: Deregulation will significantly influence public access to public broadcast media content.

H4: Deregulation will significantly influence public participation in matters of national importance.

H5: Commercialisation will significantly influence public access to public broadcast media content.

H6: Commerialisation will significantly influence public participation in matters of national importance.

\subsection{Theoretical and Conceptual Frameworks}

\subsubsection{Synopsis}

In view of the important role of public broadcast media in providing access to information and facilitating public participation in matters of national importance, and recognising the place of deregulation and commercialisation in shaping this role in Nigeria, the discourse in this paper was framed using the model of political economy of communication (see Figure 1).

$$
\text { ECONOMY POLITICS }
$$

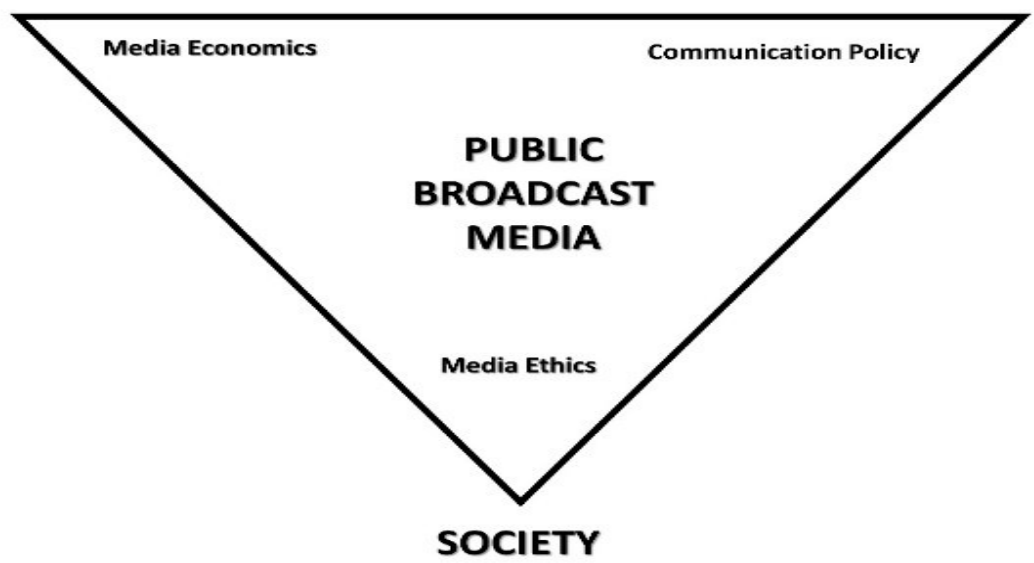

Figure 1: The political economy of communication media model represented by an inverted pyramid, symbolising the people (masses) at the bottom while the elites (the bourgeoisies and the powerful people always occupy the vintage points in every society (Source: [62]). 


\subsubsection{The Political Economy of Communication Model}

The political economy approach to the study of communication draws heavily from the Marxian and NeoMarxian traditions, even though [63] posits that it predates the Marxian tradition. Citing Knies et al., Reference [63] notes that "such a view, however, obscures an older, trans-Atlantic political economy tradition forged by Europe and North American scholars who made communications media central objects of their analyses in the late-19th and early-20th centuries" (p.2). The current political economy approach to the study of communication focuses on the incorporation of communication into the wider corporate economy and its exploitative and undemocratic tendencies. It looks at giant communications industries, their growth, power, influence and impact throughout the whole world. [64, 65]. Using Neo-Marxian analytical tools to analyse communications, the works of [66] and [67] have emphasised class power, the integration of communication within the wider capitalist economy and state policies that promote liberalisation, commercialisation and privatisation of the communication industries. It has analysed this market - based policies to instruments of social communication and its consequences $[45,66]$.

Reference [60, 61] captures the thrust of this argument in the following way: the global pressure to privatisation and commercialisation then led political economy to address the instrumental and structural roots of the process. More recently and particularly in response to the tendency of privatisation to create disparities in access and changes in content that reflect largely market pressures, political economy has revived interest in exploring a wide range of alternative forms of the public sphere, civil society and community communication $[62,61]$. Political economy of communication places media as central to the production and reproduction of a social system. The media in society contributes to socialisation, political education and mobilisation. Political economy of communication places emphasis on production or supply rather than consumption or demand. It also places the media within a wider social relation of production [2].

The conceptual framework (see Figure 2) consists of four variables - two independent variables (deregulation and commercialisation) and two dependent variables (access and participation).

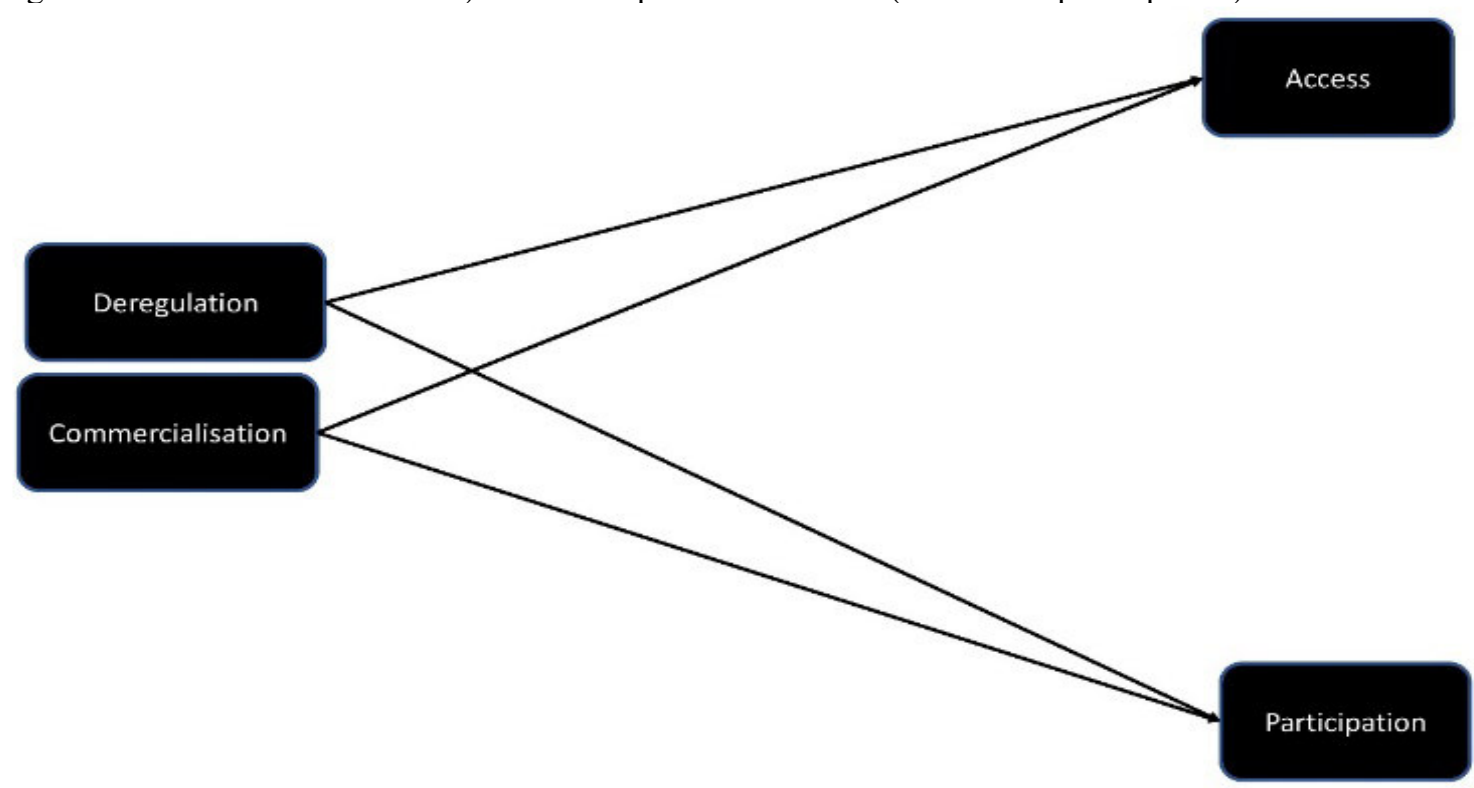

Figure 2: The proposed conceptual framework of the paper (Source: Author

The arrows in the conceptual framework show the directions of influence. Using a quantitative approach involving, e.g., Pearson's correlation analysis/regression analysis the degree of the significance of the relationship between the independent variables and the dependent variables will be measured, whence the levels of the influences of the factors of political economy proposed for investigation, namely deregulation and commercialisation will be determined through hypotheses testing.

\section{Conclusion}

This paper seeks to discuss to and analyse what influences the policy of deregulation and commercialization of the media could have had on radio broadcasting from 1992 when the policy was established to date, a period of 27 years. The study proposed that deregulation and commercialization has constrained and constricted radio's public service functions of access and participation in Nigeria since policy of deregulation. Deregulation should therefore mean that these disadvantaged sectors have substantially greater access to the public broadcast media of communication. For example, the findings of a study conducted by [4] showed that deregulation and commercialisation may have increased the gap between those who have access to information and the means of 
using it and influencing others and those who do not have these capabilities. Reference [68] engages in what has been called the discourse of deregulation that increased choice, diversity and democratic communication will emerge automatically as it were given full-fledged deregulation. It is the product of what [69] calls "the fallacy of trying to model the system of social communication on the liberal market place".

Deregulation of the communication broadcast environment has not delivered information to those who need it most. It has not given greater voice to women, children and the poor. But rather it has diminished choices of content beneficial to citizens' enhancement [56]. The findings further revealed that most public broadcast stations are concentrated in urban centres, worsening the information deficiencies between the city and rural areas and alienating the privileged classes from the ordinary people. The current deregulation of broadcast media industry in the country has not changed completely the unequal information access prevalent in the society. For example, Reference [4's] study findings showed the spatial distribution of post-deregulation broadcast stations is concentrated in the big economic viable cities like Lagos, Port Harcourt, Kano, Abuja, Kaduna and Onitsha.

Furthermore, there is more access to broadcast media services than participation for the simple reason that before deregulation, there were only about 80 radio and television stations in the country. However, during the post-regulation era, we now have more than 265 radio stations [70] and 104 television stations [72, 71] (both private and public) in the country. Of the 265 radio stations in the country 61 are public (both State-Government and Federal Government-owned stations) while of the 104 television stations 82 are government-owned, both state and federal) [71, 70]. This naturally created access exponentially for a lot of radio listeners. But the demographics of this access is a different matter altogether. It still remains unclear if access to public broadcast media and participation have improved for everybody. Based on [4's] findings this appears not to be so. Because if more 265 radio stations and 104 television stations are concentrated in urban areas and economic nerve centres of the country, then access and participation may have just improved for people in urban areas and cities while still marginalising the poor and rural dwellers. Therefore, future research should focus on examining the extent to which the deregulation and commercialisation of the public broadcast industry has impacted the people's access to the media content and participation in public discourse and democracy from 1992 to 2019.

\section{References}

[1] Oketumbi, E. (2007). Gains and pains of liberalisation of broadcasting in Nigeria: A Critical assessment. Journal of Communication and Society: vol. 1(, No. 2\&3, pp. 51-62.

[2] V. Mosco (2015). "The political economy of communication: A living tradition." In Power, media, culture: A critical view from the political economy of communication (pp 35-60). London: Palgrave MacMillan.

[3] Nsereka, G. B. (2016). Challenges of public and private television stations in Nigeria: A comparative study of NTA and AIT. The International Journal of Humanities and Social Studies, 4(4), 99-109.

[4] Njoku, G. (2018). The political economy of deregulation and commercialization of radio broadcasting in Nigeria, 1992-2017: An assessment of access, participation, content and peacebuilding. Unpublished PhD thesis, Universität Autonoma de Barcelona, Barcelona Spain.

[5] Bwala, M. H. (2014). Structural adjustment programme. Research on Humanities and Social Sciences, 4(7), 98-108.

[6] TCPC Final Report (1993). Commercialisation, vol. 111. Lagos, Nigeria: Federal Government Printers

[7] Asogwa, C. E. \& Asemah, E. S. (2012). News commercialisation, objective journalism practice and the sustenance of democracy in Nigeria. Higher Education of Social Science, 3(2), 27-34. doi: 10.3968/ j. hess. 1927024020120302.1817

[8] Oso, L. (2012). News for sale! The challenges and implications of the commercialisation of News in Nigeria. In L. Oso, D. Soola \& U. A. Pate (Eds.), Media, governance and development: Issues and trends (pp.83104). KG, Saarbrucken, Germany: LAP Lambert Academic Publishing.

[9] Cage, J. (2016). Saving the media: Capitalism, crowdfunding and democracy. Cambridge, Massachusetts: The Belknap Press of Harvard University Press.

[10] Gonzalez-Manet, E. (1988). The hidden war of information. New Jersey: Ablex Publishing Corporation.

[11] Nwuzor, A (2014). Redefining political terrorism: Nigerian media and the crisis of democratisation. African Research Review, 8(2), 96-117.

[12] Mohammed, J. B. (1994). Democratisation and the challenge of private broadcasting in Nigeria. Africa Media Review, 8(1), 56-70.

[13] Jakubowicz, K. (2011). Public service broadcasting and public policy. In R. Mansell \& M. Raboy (Eds.), The Handbook of global media and communication policy. New York: Blackwell Publishing Ltd.

[14] Hanretty, C. (2012). Public service broadcasting's continued rude health. London: The British Academy.

[15] Foster, R. \& Meek, K. (2008). Public service broadcasting in the United Kingdom. A longer-term view. London: The Social Market Foundation.

[16] Santas T. \& Asemah, E. S. (2013). Public perception of the role rural broadcasting in rural development in Nigeria. Journal of Sustainable Development in Africa, 15(7), 23-42. 
[17] Anifowose, B. O. (2013). Exploring radio as a means of disseminating development messages. Department of Communication and Language Art. University of Ibadan, Ibadan. Nigeria.

[18] Ariyo, et al. (2013). Assessment of the role of mass media in the dissemination of agricultural technologies among farmers in Kaduna North Local Government Area of Kaduna State, Nigeria. Journal of Biology, Agriculture and Healthcare, 2(3), 56-77.

[19] Bratic, V. (2015). Beyond journalism: Expanding the use of media in peacebuilding. In J. Hoffman \& V. Hawkins (Eds.), Communication and peace: Mapping an emerging field. New York: Routledge.

[20] Smulyan, R. S. (1985). "And Now a word from our sponsors": Commercialisation of American broadcast radio. (Unpublished PhD Thesis) Yale University, United States of America.

[21] Bogart, L. (2000). Commercial culture, the media system and the public interest. New Jersey: Transaction Publishers.

[22] Benjamin, L. (2013). Susan Smulyan, Selling radio: The commercialisation of American broadcasting, 1920-1934. American Journalism, 11(3), 293-294. doi: 10.1080/08821127.1994.10731655

[23] Bagdikian, B. H. (2004). The new media monopoly: A completely revised and updated edition with seven new chapters. Boston: Beacon Press.

[24] Statista (2017). Radio revenue in North America from 2008 to 2017, by source (in billion U.S. Dollars). Retrieved from https://www.statista.com/statistics/260153/radio-revenue-in-northamerica-by-source/

[25] Adejumobi, J. A. (1974). The development of radio broadcasting in Nigeria, West Africa. (Unpublished MA thesis), North Texas University, USA.

[26] FCC News (2017). FCC gives non-commercial stations greater fundraising flexibility. Retrieved from https://www.fcc.gov/document/fcc-gives-noncommercial-stations-greaterfundraising-flexibility

[27] Brian Stelter (2017). PBS and NPR are ready to fight budget cuts - again - CNN Money. Retrieved from http://money.cnn.com/2017/03/16/media/public-media-pbs-npr-budgetcuts/index.html

[28] Wheeler, T. (2017). Trump's FCC deregulation threatens local broadcasting. Retrieved from https://www.brookings.edu/blog/techtank/2017/07/11/trump-fcc-deregulation-threatens-localbroadcasting/

[29] Bagdikian, B. H. (1992). The media monopoly. Boston MA: Beacon.

[30] Powell, J. T. \& Gaie, W. (Eds.). (1987). Business of broadcasting: The broadcast industry looks at itself. New York: Quorum.

[31] Blakely, R. J. (1979). To serve the public interest: Educational broadcasting on the United States. New York: Syracuse University Press.

[32] Lewis, P. M. \& Booth, J. (1989). The invisible medium, public, commercial and community radio. London: Macmillan Education Ltd.

[33] Coase, R. H. (1974). The market for goods and the market for ideas. American Economic Review, 64(2), 231-239.

[34] Armstrong, M. \& Weeds, H. (2005). Funding public service broadcasting in a digital world. Retrieved from https://pdfs.semanticscholar.org/f4df/720de9225ca76c7f833ed4d7940ddda79a40.pdf

[35] Stuhmeier, T. \& Wenzel, T. (2012). Regulating advertising in the presence of public service broadcasting. Heinrich-Heine-Universität Düsseldorf, Department of Economics, Düsseldorf Institute for Competition Economics (DICE), Universitätsstraße 1, 40225 Düsseldorf, Germany.

[36] Mckinsey and Company. (2004). Review of public service broadcasting around the world. Mckinsey \& Company. London.

[37] BBC (2013). The public and private broadcasters across the world: A race to the top. $B B C$, London. Retrieved

from https://downloads.bbc.co.uk/aboutthebbc/insidethebbc/howwework/reports/pdf/bbc_report_public_and_priv ate broadcasting across the world.pdf

[38] The Guardian Newspaper, UK (2015). How public service broadcasting shape up worldwide. Retrieved from https://www.theguardian.com/media/2015/jul/19/public-sector-broadcastingworldwide-bbc

[39] Raboy, M., Buckley, S., Mendel, T., Price, M. E., Duer, K. \& Siochru, S. O. (2011). Broadcasting, voice and accountability: A public interest approach to policy, law and regulations. Washington, DC: The World Bank Group.

[40] Mackay, I. K. (1964). Broadcasting in Nigeria. Ibadan: University Press.

[41] Manyozo, L. (2012). People's radio: Communicating change across Africa. Penang: Southbound.

[42] Adepoju A. (Ed.). (1993). The impact of structural adjustment on the population of Africa. London: UNFPA/Heine/James Currey.

[43] Goodfriend, E. (2012). Peacebuilding and public service media: Lessons from Star Radio and media development in Liberia. (Unpublished MSc Dissertation), London School of Economics, UK.

[44] Chioma, P. E. (2014). A comparative evaluation of the pre-and post-deregulation challenges of broadcasting in Nigeria. Journal of Research and Development, 1(8), 97-109.

[45] Ferguson, M. (1990). New communication technologies and public interest. London: Sage Publication. 
[46] Tracey, M. (2011). The decline and fall of public service broadcasting. Oxford Scholarship Online.

[47] Tracey, M. (1998). The decline and fall of public service broadcasting. New York: Oxford University Press.

[48] Blumler J. G. \& Gurevitch, M. (1995). The crisis of public communication. London: Routtledge.

[49] Putnam, R. D. (2001). Bowling alone: The collapse and revival of American community. New York: Simon and Schuster.

[50] Friedman, M (1962, 1982) Capitalism and freedom. Chicago: The University of Chicago Press.

[51] Mosco, V. \& Wasko, J. (1988). The political economy of information. London: Sage.

[52] Amin, S. (2000). Capitalism in the age of globalisation: The management of contemporary society. New York: Zed Books.

[53] Moemeka, A. (2000). Communication for development: A new pan-disciplinary perspective. New York: State University of New York Press.

[54] Myers, M. (2008). Radio and development in Africa: A concept paper. Ottawa: International Development Research Centre.

[55] Manyozo, L. (2005). The practice of participation in broadcasting for development in post-independent Malawi, Journal of Social Development in Africa, 20(1), 77-105.

[56] Castells, M. (1989). The information city: Information technology, economic restructuring and the urbanregional process. Oxford: Basil Blackwell.

[57] Katatzi-Whitlock, S. (2011). The political economy of political ignorance. In J. Wasko, G. Murdock \& H. Sousa (Eds.), The handbook of political economy of communications. Oxford, UK: WileyBlackwell.

[58] Nafiz, A. Z. (2012). Reaching the community through community radio: Readjusting to the new realities: A case study investigating the changing nature of community access and participation in three community radio stations in three countries, New Zealand, Nepal and Sri Lanka. (Unpublished PhD thesis), University of Canterbury, United Kingdom.

[59] McChesney, R. \& Schiller, D. (2003). The political economy of international communications foundation for the emerging global debate, ownership and regulation. Technology, Business and Society Programme. Paper Number 11. United Nations Research Institute for Social Development.

[60] Preston, W., Herman, E. \& Schiller, H. (1989). Hope and folly: The United States and UNESCO, 1945 1985. Minneapolis: University of Minnesota Press.

[61] Mosco, V. (1996). The political economy of communication: Rethinking and renewal. New York: Sage.

[62] Calabresse and Mihal (2011). Liberal fictions (The public-private dichotomy in media policy) in J. Wasko, G. Murdock \& H. Sousa (Eds.), The handbook of political economy of communications. Oxford, UK: WileyBlackwell.

[63] Freie Universitat Berlin (2010 May 2). Communication policy/media economic. Retrieved from https://www.polsoz.fu-berlin.de/en/kommwiss/arbeitsstelen/komunkationspolitik/profil/index.html

[64] Winseck, D. (2016). Reconstructing the political economy of communication for the digital media age. The political Economy of Communication, 4(2), 73-114. Retrieved from http://www.polecom.org/index.php/polecom/article/view/72

[65] Schiller, H. (1989). Culture, Inc: The corporate takeover of public expression. New York: Oxford University Press.

[66] Smythe, D. W. (1981). Dependency road: Communications, capitalism, consciousness and Canada. Norwood, NJ: Ablex Publishing Corp.

[67] Garnham, N. (1990). Capitalism and communication: Global culture and the economics of information. Newbury Park CA: Sage.

[68] Murdock, P. \& Golding, P. (1977). Capitalism, mass media and the ideological effect. In J. Curran et al. (Eds.), Mass communication and society. London: Edward Arnold.

[69] Downing, J. D. H. (2011). Media ownership, concentration and control: The evolution of debate. In J. Wasko, G. Murdock \& H. Sousa (Eds.), The handbook of political economy of communications. Oxford UK: Wiley-Blackwell.

[70] Szecsko, T. (1986). Theses on the democratisation of communication. In Communication and innovation: Notes from Hungary (pp.77-81). Budapest: Mass Communication Research Centre.

[71] IMS (2017). Radio stations in Nigeria (Government and private commercial). Institute for Media and Society (IMS), October 29. Retrieved from https://limesoimeso.org/radio-stations-nigeria-governmentprivate-commercial/ 